УДК 633.13:633.16:631.816.12

(C) 2013

Гирка А. Д., кандидат сільськогосподарських наук, Кулик І. О., Андрейченко О. Г., аспіранти *

Інститут сільського господарства степової зони НААН

\title{
УРОЖАЙНІСТЬ ВІВСА ТА ЯЧМЕНЮ ЯРОГО ЗАЛЕЖНО ВІД ПОПЕРЕДНИКА І ЗАСТОСУВАННЯ МІКРОДОБРИВ У ПІВНІЧНОМУ СТЕПУ
}

\section{Рецензент - доктор сільськогосподарських наук, професор Г. П. Жемела}

\begin{abstract}
Представлені результати вивчення впливу застосування мікродобрив на урожайність вівса та ячменю ярого в північному Степу. Встановлено, шьо комплексне застосування мікродобрив за обробки насіння та обприскування посівів забезпечує підвищення врожайності вівса на $10 \%$, ячменю - на $15 \%$ залежно від попередника. Виявлено, щзо більи адаптованим до посушливих умов с овес: він забезпечив на 0,72 m/2а (30,9\%) більшу врожайність порівняно з ячменем. Кращим попередником для згаданих культур є пшениия озима, вирощування після якої забезпечувало формування врожайності зерна вівса на 10,1 та 18,1\%, а ячменю - на 20,4 та 23,7\% більше, ніж після кукурудзи МВС та соняшника відповідно.
\end{abstract}

Ключові слова: овес, ячмінь ярий, попередники, мікродобриво, зерно, урожайність.

Постановка проблеми. Овес і ячмінь ярий одні $з$ найбільш поширених хлібних злаків у світі. Слід зауважити, що значна частина посівів цих культур розташована в зоні степу, який характеризується недостатнім і нестійким зволоженням та високим температурним режимом, а негативне варіювання погодних умов призводить до суттєвого зниження й значного недобору рівня врожаю зерна. Однією з головних причин низької реалізації генетичного потенціалу сучасних сортів вівса та ячменю $є$ недостатня обгрунтованість технологічних заходів адаптації рослин до несприятливих умов вирощування, що поглиблюється існуючою соціально-економіч-ною кризою і характеризується диспаритетом цін на МТР та закупівельними цінами на вирощену сільськогосподарську продукцію. Вирішення цієї проблеми можливе шляхом розробки нових й удосконалення існуючих елементів технології вирощування ярих колосових культур після різних попередників, у тому числі й за рахунок оптимізації мінерального живлення для регуляції ростових і продукційних процесів вівса та ячменю $[1,5]$.
Аналіз останніх досліджень і публікацій, у яких започатковано розв'язання проблеми. За сучасних ринкових умов й обмежених економічних можливостях значно зменшився обсяг використання органічних і мінеральних добрив, що зумовлює необхідність пошуку альтернативних джерел живлення рослин, зокрема вівса та ячменю ярого. Для нормального розвитку рослинний організм потребує крім макроелементів ще й мікроелементи. Найбільш ефективними й економічно вигідними способами використання мікродобрив є обробка насіння і позакореневе підживлення вегетуючих рослин. Потрапляючи на поверхню листка, мікроелементи проникають у його тканини і включаються в біохімічні реакції обміну в рослині. Даний прийом значно підвищує коефіцієнт використання мікроелементів і забезпечує рослини необхідним набором мікроелементів у період формування репродуктивних органів. Це дає змогу збагачувати мікроелементами зерно сільськогосподарських культур й отримувати повноцінний урожай, що містить оптимальну кількість для даного сорту цукрів, амінокислот та вітамінів $[2,4,6]$.

Мета і завдання досліджень. Метою роботи було виявлення ефективних шляхів підвищення зернової продуктивності вівса та ячменю ярого у північному Степу. Актуальним $\epsilon$ питання з виявлення найбільшої ефективності застосування мікродобрив при інкрустації насіння та обприскуванні вегетуючих посівів вівса та ячменю ярого після різних попередників.

Для досягнення поставленої мети передбачалося вирішення головного завдання - 3 урахуванням рівня адаптивності культур оптимізувати агротехнічні заходи комплексного застосування системи мінерального живлення при вирощуванні вівса та ячменю ярого після різних попередників у північному Степу України.

* Науковий керівник - кандидат сільськогосподарських наук А. Д. Гирка 
Методика проведення досліджень. Із метою вирішення цього важливого наукового завдання у лабораторії технології вирощування ярих зернових та зернобобових культур на базі Ерастівської дослідної станції ІСГСЗ НААН (П'ятихатський район Дніпропетровської обл.) закладено польовий дослід із вивчення впливу різних попередників і системи мінерального живлення на продуктивність рослин вівса та ячменю. Дослідження проводили за загальновідомими методиками $[3,7]$. Грунт дослідних ділянок - чорнозем звичайний малогумусний важкосуглинковий. Вміст гумусу в орному шарі грунту $(0-30$ см) $-4,0$ $4,5 \%$, загального азоту $-0,23-0,26 \%$, фосфору $0,11-0,16 \%$, калію - 2,0-2,5\%, pH водної витяжки - 6,5-7,0. Висівали сорт вівса Скакун, ячменю ярого Галактик, застосовували мікродобриво Реаком-СР-Зерно. Технологія вирощування (крім досліджуваних питань) - загальноприйнята для зони. Розміщення варіантів у польовому досліді систематичне, повторність триразова, облікова площа ділянок $50 \mathrm{~m}^{2}$. Попередники - пшениця озима, кукурудза МВС, соняшник.

Результати досліджень. Метеорологічні умови в роки проведення досліджень (2011-2012 рр.) характеризувалися контрастністю, що дало змогу всебічно оцінити їх вплив на реалізацію потенціалу зернової продуктивності рослин вівса та ячменю ярого. Так, у 2011 р. за вегетаційний період випало 245 мм опадів, що на 25 мм більше за середню багаторічну норму, середня температура повітря склала $+17,7^{\circ} \mathrm{C}$. Досить посушливим був 2012 р., який характеризувався вищою температурою повітря $\left(+24,1^{\circ} \mathrm{C}\right.$, що на $9,1^{\circ} \mathrm{C}$ більше норми) та дефіцитом атмосферних опадів (за вегетацію випало 172 мм, що на 50 мм менше норми). Таким чином, більш сприятливі умови вегетаційного періоду для росту і розвитку рослин вівса та ячменю склалися у 2011 році.

Аналіз даних свідчить, що обробка насіння i вегетуючих рослин мікроелементами сприяла збільшенню висоти рослин й інших біометричних показників вівса та ячменю. Так, внаслідок комплексного застосування мікродобрив висота рослин вівса та ячменю була на 2-6\% більша, ніж у варіантах без використання мікроелементів. Обробка насіння і вегетуючих рослин мікродобривами також позитивно впливала на наростання вегетативної маси. Виявлено, що за інкрустації насіння мікродобривами продуктивна кущистість у вівса та ячменю збільшується на 1-4\%; в результаті обприскування посівів вона зростала у вівса на 6-10\%, а в ячменю - на $1-5 \%$. Поєднання інкрустації насіння та обприс- кування посівів сприяло збільшенню показника продуктивної кущистості вівса на 10-12\%, ячменю - на 6-10\%. Внаслідок комплексного застосування мікродобрив довжина волоті вівса зростала на $1,5 \mathrm{~cm}$, або $11,3 \%$, а колосу ячменю - на 0,65 см, або 10,5\%, що приводило до збільшення озерненості волоті (колосу).

Рівень зернової продуктивності різних сільськогосподарських культур, у тому числі й вівса та ячменю, значно залежить від вибору найкращого попередника. Експериментальним шляхом встановлено, що за рахунок використання мікродобрив у посівах вівса та ячменю і підбору найкращого попередника можливо суттєво підвищити урожай зерна навіть у досить посушливих умовах Степу України (див. табл.).

Вплив попередників на реалізацію потенціалу продуктивності вівса та ячменю був істотним у всіх варіантах досліду. В середньому за 2011-2012 pр. у варіантах після попередника пшениця озима формувалася найбільша врожайність вівса - 3,23-3,53 т/га, проти 2,93-3,19 т/га - після кукурудзи МВС та $2,67-2,90 \mathrm{t} / г \mathrm{a}-$ після соняшника. У ячменю ярого ці показники становили, відповідно, 2,70-3,32 т/га, 2,09-2,70 та 1,96-2,73 т/га.

Застосування мікродобрив забезпечувало підвищення врожайності вівса та ячменю, однак вплив їх після різних попередників проявлявся не однаково. Так, за період проведення експериментальних досліджень (2011-2012 рр.) використання мікродобрив за обробки насіння підвищувало врожайність вівса після пшениці озимої на 0,10 т/га, а ячменю - на 0,13 т/га. Після кукурудзи МВС та соняшнику також отримано приріст врожайності відносно контролю. Результати досліджень свідчать про те, що обробка насіння мікродобривом сприяла приросту врожайності вівса та ячменю за рахунок збільшення енергії проростання, польової схожості та приросту біомаси, що було характерним для початкових етапів органогенезу рослин.

У разі застосування Реакому-СР-Зерно у фазі кущіння за рахунок обприскування вегетуючих рослин отримано дещо більший приріст врожайності у вівса - 0,15 т/га (після пшениці озимої), 0,10 т/га (після кукурудзи МВС) і 0,09 т/га (після соняшнику); а в ячменю, відповідно, 0,19 т/га, 0,09 i 0,11 т/га.

За рахунок комплексного застосування мікродобрива Раком-СР-Зерно (3 л/т) для обробки насіння + Реаком-СР-Зерно (3 л/га) для обприскування рослин у фазі кущіння отримано найбільші прирости врожайності у вівса - 0,30 т/га 
Урожсайність вівса та ячменю ярого залежно від використання мікродобрива Реаком-СР-Зерно після різних попередників (2011-2012 pp.), m/2a

\begin{tabular}{|c|c|c|c|}
\hline \multirow[b]{2}{*}{ Варіант внесення мікродобрива Реаком-СР-Зерно (Фактор А) } & \multicolumn{3}{|c|}{ Попередник (Фактор В) } \\
\hline & $\begin{array}{c}\text { пшениця } \\
\text { озима }\end{array}$ & $\begin{array}{l}\text { кукурудза } \\
\text { МВC }\end{array}$ & соняшник \\
\hline \multicolumn{4}{|l|}{ Овес } \\
\hline Контроль & 3,23 & 2,93 & 2,67 \\
\hline Раком-СР-Зерно (3 л/т) - обробка насіння & 3,33 & 2,98 & 2,71 \\
\hline $\begin{array}{c}\text { Реаком-СР-Зерно (3 л/га) - обприскування рослин } \\
\text { у фазі кущіння } \\
\end{array}$ & 3,38 & 3,03 & 2,76 \\
\hline $\begin{array}{l}\text { Раком-СР-Зерно (3 л/т) - обробка насіння + Реаком-СР-Зерно } \\
\text { (3 л/га) - обприскування рослин у фазі кущіння }\end{array}$ & 3,53 & 3,19 & 2,90 \\
\hline \multicolumn{4}{|c|}{$\mathrm{HIP}_{05}$, т/га, для фактора $\mathrm{A}-0,07 ;$ для фактора $\mathrm{B}-0,11$} \\
\hline \multicolumn{4}{|c|}{ Ячмінь } \\
\hline Контроль & 2,57 & 2,09 & 1,96 \\
\hline Раком-СР-Зерно (3 л/т) - обробка насіння & 2,70 & 2,14 & 2,05 \\
\hline $\begin{array}{c}\text { Реаком-СР-Зерно (3 л/га) - обприскування рослин } \\
\text { у фазі кущіння }\end{array}$ & 2,76 & 2,18 & 2,07 \\
\hline $\begin{array}{c}\text { Раком-СР-Зерно (3 л/т) - обробка насіння + Реаком-СР-Зерно } \\
\text { (3 л/га) - обприскування рослин у фазі кущіння }\end{array}$ & 2,93 & 2,32 & 2,27 \\
\hline
\end{tabular}

(після пшениці озимої), 0,26 т/га (після кукурудзи $\mathrm{MBC}$ ) та 0,13 т/га (після соняшнику). В ячменю ці показники становили відповідно 0,36 т/га, 0,23 та 0,21 т/га по попередниках.

Висновки. Підсумовуючи викладені результати експериментальних даних, слід зазначити наступне. Використання у сучасному зерновиробництві мікродобрив у поєднанні 3 правильним вибором попередника дає реальну можливість отримати вагомий приріст врожайності зерна. Дослідженнями встановлено, що під впливом досліджених елементів агротехніки, зокрема поєднання обробки насіння 3 обприскуванням

\section{БІБЛІОГРАФІЯ}

1. Борисоник 3. Б. Яровые колосовые культуры. Издание второе, переработанное и дополненное / 3. Б. Борисоник. - К. : Урожай, 1975. - С. 176 (на украинском языке).

2. Булихін С. Ю. Мікроелементи в сільскому господарстві / С. Ю. Булыгин, Л. Ф. Демишев, В. А. Доронин [та ін.] // 3-є вид., доповнене. - Дніпропетровськ : Січ, 2007. $-100 \mathrm{c}$.

3. Доспехов Б. А. Методика полевого опыта / Б. А. Доспехов - М. : Агропромиздат, 1985. $351 \mathrm{c}$.

4. Лихочвор В. В. Біологічне рослинництво / В. В. Лихочвор - Львів : НВФ «Українські технології», 2004. -312 c. вегетуючих рослин у фазі кущіння мікродобривом Реаком-СР-Зерно, збільшується врожайність вівса на $10 \%$, а ячменю ярого - на $15 \%$ залежно від попередника. Виявлено, що більш адаптованим до посушливих умов Степу є овес, який за роки проведення експерименту забезпечив на 0,72 т/га (30,9\%) більшу врожайність порівняно 3 ячменем. Кращим попередником для згаданих культур є пшениця озима, вирощування після якої забезпечувало формування врожайності зерна вівса на 10,1 та 18,1 \%, а ячменю - на 20,4 та 23,7 \% більше, ніж після кукурудзи МВС та соняшника відповідно.

5. Митрофанов А. С. Овес. (изд. 2-ое, перераб.) / А. С. Митрофанов, К. С. Митрофанова. - М. : Колос, 1972. - 269 с. (с ил.)

6. Халеикий С. П. Технология получения высокой урожайности овса / С. П. Халецкий, С. В. Сорока, В. М. Ковтун [и др.] // Современные ресурсосберегающие технологи производства растениеводческой продукции в Беларуси: сб. науч. материалов. - Минск : ИВЦ Минфина, 2007. - 448 с.

7. Циков B. C. Методические рекомендации по проведенню полевых опытов с зерновыми, зернобобовими и кормовими культурами / В. С. Циков, Г. Р. Пикуш. - Днепропетровск, 1983. $-46 \mathrm{c}$. 